\title{
Hydrological Impacts of Urbanization and Urban Roof Water Harvesting in Water-limited Catchments: A Review
}

\author{
Willis Gwenzi • George Nyamadzawo
}

Received: 28 May 2014 / Accepted: 12 September 2014 / Published online: 20 September 2014

(C) Springer International Publishing Switzerland 2014

\begin{abstract}
Roof water harvesting is a potential source of water for domestic and livelihood uses in water-scarce urban areas of the world such as sub-Saharan Africa (SSA). However, little is known about the hydrological impacts of incorporating roof water harvesting on on-site and downstream hydrology of urbanized catchments. Therefore, the current review investigates the effects of urbanization and urban roof water harvesting on hydrological processes, rainfall-runoff relationships, groundwater recharge and water contamination, and highlights future research directions. The review showed that the urban heat island effect increases the frequency and magnitude of convective storms. The high proportion and connectivity of impervious surfaces reduce infiltration, thereby increasing the runoff coefficient and Hortonian runoff. Urbanization reduces the minimum threshold rainfall for runoff generation, resulting in multi-peak hydrographs reflecting the contribution of both pervious and impervious surfaces. Urban roof water harvesting increases catchment lag time, but reduces downstream peak and total discharge, baseflow and flow velocity. Utility trenches, tunnels and buried structures form a complex network resembling a shallow urban karst system, which provides preferential flow pathways for groundwater recharge by imported water via leakages. Contrary to the widely held notion that urbanization reduces groundwater recharge by increasing impervious surfaces, empirical evidence shows significant urban-enhanced recharge in water-limited urban catchments. However, we contend that excessive groundwater abstraction for multiple uses in water-scarce regions offsets the urban-enhanced recharge, resulting in groundwater depletion. Due to the overriding collective effects of reduced soil moisture and vegetation cover on evapotranspiration in water-limited environments, we conclude that urbanization lowers evapotranspiration. Urban roof water harvesting short-cuts the urban water cycle, thereby minimizing the risk of runoff contamination that could occur during its extended flow over contaminated land surfaces. Contaminated sources of recharge, such as wastewater leakages coupled with the urban karst system, promote groundwater pollution. Overall, urban roof water harvesting imparts additional
\end{abstract}

W. Gwenzi $(\bowtie) \cdot$ G. Nyamadzawo

Department of Soil Science and Agricultural Engineering, University of Zimbabwe, P.O. Box, MP167Mt.

Pleasant, Harare, Zimbabwe

e-mail:wgwenzi@yahoo.co.uk

Willis Gwenzi

e-mail: wgwenzi@agric.uz.ac.zw

G. Nyamadzawo

Department of Environmental Science, Bindura University of Science Education, Box 1020, Bindura, Zimbabwe 
complexity to urban catchments, and has potentially adverse effects on ecohydrology. Understanding these impacts is critical for planning, designing and operation of urban roof water harvesting systems. Future research may provide a comprehensive understanding of these impacts by combining hydrological measurements and process modelling in urbanized catchments incorporating roof water harvesting.

Keywords Contamination - Evapotranspiration - Impervious Surfaces · Hortonian Runoff · Groundwater Recharge · Multi-Peak Hydrograph · Rainfall-Runoff Relationships

\section{Introduction}

Most water-scarce regions of the world are characterized by annual potential evapotranspiration exceeding annual rainfall. Water-limited catchments experience highly episodic rainfall (Gwenzi 2010; Gwenzi et al. 2012; 2013) resulting in high temporal and spatial variability of surface water resources. For example, sub-Saharan Africa (SSA) is prone to frequent hydroclimatic risks such as droughts, dry spells and floods (Ngigi et al. 2005, 2007), making the provision of water to sustaining livelihoods, food security and public health in SSA a challenge. With an annual population growth rate of $2.2 \%$, the total population of SSA is projected to reach 1.2 billion by 2015 (UN 2011). The resulting increase in demand for the limited fresh water resources, together with limited investment in the water sector, present a challenge to the provision of basic services such as water and sanitation.

Currently, most urban areas in developing countries experience erratic water supplies. Increasing rural-urban migration in search of better opportunities and living conditions could further increase urban population and demand for services. Rural-urban migration is predicted to increase due to accelerated land degradation (UNEP/ISRIC 1991), increasing human and livestock population, and the projected shortage of land in rural areas. Such migration often results in informal urban and peri-urban settlements, which are not even connected to the highly centralised urban water supply systems. As a result, unconnected households resort to readily available but unsafe water sources, such as open water bodies and shallow groundwater wells, to meet their daily water requirements. Such water sources pose significant public health risks, leading to the outbreaks of waterborne diseases such as cholera and typhoid in Zimbabwe. Current efforts to provide clean urban water supplies in developing countries largely focus on increasing water supplies through infrastructural development such as construction of dams, water treatment systems and drilling of boreholes. Such highly centralised systems rarely benefit the vulnerable urban and peri-urban communities in informal settlements.

Roof water is considered cheaper and more readily available than highly centralised conventional water supplies, while being safer than open water bodies and shallow groundwater. Despite the several potential benefits, the promotion of roof water harvesting to provide or supplement existing water resources in urban and peri-urban areas is largely overlooked in most parts of the world, including SSA. Although there is little data from a few water-scarce regions, particularly Australia (Coombes 2002) and India (Jebamalar and Ravikumar 2011), there is limited information on large-scale roof water harvesting systems for urban water supply from most of the water-scarce regions of the world, including SSA. In most of these regions, current legislation and water policies pay little attention to roof water harvesting systems. Increasing demand for fresh water resources and limited investment in the water sector have drawn recent attention to non-conventional water supplies such as recycling of treated wastewater (Haarhoff and van der Merwe 1996) and roof water harvesting for domestic supply (Mwenge-Kahinda et al. 2007). 
Water harvesting systems entail closing the water balance at a local scale before the water interacts with contaminants. Principles of water harvesting systems include using water where and when it falls. A roof water harvesting system consists of five components: (1) a catchment consisting of impervious area; (2) a runoff collection system for concentrating the runoff often consisting of a network of gutters; (3) a conveyance system consisting of pipework; (4) a storage tank or reservoir; and (5) subsequent water use for multiple domestic and productive purposes. In developing countries, potential domestic uses include laundry, toilet flushing, landscaping, cooking and drinking, while productive uses include watering of household gardens and livestock.

Studies conducted on water harvesting systems in water-scarce environments broadly focussed on three themes: (1) development and evaluation of design procedures for roof water harvesting systems for household and institutional supply (Liaw and Tsai 2004); (2) water quality and its determinants mainly in developed countries (Farreny et al. 2011); and (3) water harvesting systems in agriculture to improve livelihoods and food security in drought-prone areas in developing countries (Ngigi et al. 2005, 2007). For example, in SSA, studies have investigated the impacts of integrating water harvesting systems and soil fertility management on field-scale rainfall partitioning, crop yields and their impacts on livelihoods and food security in water-scarce regions (e.g., Ngigi et al. 2005, 2007; Dile et al. 2013). Water harvesting systems may have a profound effect on catchment water balance and downstream hydrology, but there is a scarcity of studies documenting such impacts in urban catchments.

Urbanized catchments have unique surface and thermal properties and hydrology, and large-scale roof water harvesting systems could impart further complexity to the system. Therefore, without proper understanding of the impacts, roof water harvesting may offset the water balance and cause significant on-site and downstream ecohydrological impacts. An understanding of the hydrological impacts of large scale urban roof water harvesting is critical for planning, designing and operation of such systems. Ideally, a combination of field measurements and hydrological modelling in a catchment with large-scale water harvesting systems would yield a comprehensive understanding of the hydrological impacts of roof water harvesting. The current study relies on literature review and conceptual analysis to investigate the effects of urbanization and roof water harvesting on on-site and downstream hydrology of water-limited catchments. The specific objectives were: (1) to investigate the effects of urbanization and roof water harvesting system on hydrological processes, rainfall-runoff relationships, groundwater recharge and water contamination; and (2) to identify priority future research on urban roof water harvesting systems in water-scare regions, such as SSA.

To address the research objectives, a combination of literature review, conceptual water balance analysis and the Budyko framework (Budyko 1974; Wang 2012) were used to identify and evaluate the hydrological impacts of urbanization and roof water harvesting systems. The review draws mainly from journal articles, theses, books and conference papers published in the past 20 years. However, due to lack of comprehensive empirical data on large-scale urban roof water harvesting systems, the application of water balance analysis and the Budyko framework was limited to qualitative interpretations. The review focuses on the hydrological impacts of urbanization and roof water harvesting systems on-site and downstream. Downstream hydrology focuses on aggregate behaviour such as runoff at the catchment discharge point, while onsite impacts refers to localized effects at the point of water harvesting.

\section{The Case of Urban Roof Water Harvesting Systems in Water-scarce Regions}

The provision of water for domestic and productive uses is critical for sustaining livelihoods, food security and public health particularly in water-scarce catchments. High urban population 
growth, lack of investment in the water sector and increasing competition for freshwater resources among sectors make the provision of water a key challenge in these regions. Currently, most communities in informal settlements, and urban and peri-urban areas in water-scarce regions, such as SSA, experience frequent water shortages and erratic supplies. Moreover, most vulnerable communities in informal settlements and peri-urban areas are not even connected to urban water supply, which are highly centralized. Recent outbreaks in water-borne diseases, such as diarrhea, cholera and typhoid in Zimbabwe, have been linked to lack of clean water and proper sanitation facilities. Indeed, there are concerns that water-scarce regions, such as SSA, may fail to achieve the Millennium Development Goals on reducing livelihoods, food security, malnutrition and infant mortality (UN 2011).

Roof water harvesting systems at household level have the potential to provide safe and low-cost water for both domestic uses and support of livelihoods activities. Compared to runoff harvesting for agriculture (Ngigi et al. 2005, 2007), there has been limited efforts to harness urban roof runoff for domestic water supply and household livelihood activities. In addition, there has been limited funding for such initiatives. The high proportion of impervious roofs in urban and peri-urban areas provides an ideal setting for roof water harvesting for domestic water supply at household level. Roof water harvesting systems have the potential to harness the runoff before it comes into contact with the soil surface, and hence maintain its quality. Water harvesting systems are considered low cost because they reduce conveyance and pumping costs, and can be constructed from readily available material. In cases where communities have no accesses to treated water, roof runoff is consider safer and cleaner than water in rivers, reservoirs and shallow groundwater systems. In this regard, roof water harvesting systems are considered an appropriate strategy for the provision of domestic water for rural and urban households particularly in developing countries (König 2009). However, before the potential benefits of urban roof water harvesting systems are realized, there is need to understand the impacts of the practice on on-site and downstream hydrology.

\section{Impacts on Catchment Properties and Hydrology}

Water-limited environments are characterized by annual potential evapotranspiration exceeding annual precipitation (Gwenzi et al. 2012; 2013). Hydrological processes, such as infiltration, runoff and groundwater recharge, are highly seasonal and episodic, and exhibit non-linear and threshold-like behaviour (Gwenzi 2010; Gallo et al. 2013). Urbanization potentially alters catchment properties and microclimate, which in turn influence on-site and downstream hydrological processes, rainfall-runoff relationships, groundwater recharge, water contamination and the overall catchment water balance.

\subsection{Catchment Characteristics}

In natural catchments, hydrological processes exhibit high spatial and temporal complexity and heterogeneity (Kirchner 2009). Urbanization may reduce the complexity and heterogeneity by altering catchment characteristics through clearing vegetation, increasing the proportion and connectivity of impervious surfaces and altering the natural topography such as slope steepness, orientation and length. The degree of imperviousness in the built environment is related to the ecohydrological impacts of urbanization (Kuang and Fu 2013). The high proportion of impervious surfaces and the associated changes in slope steepness and orientation substantially increase the runoff coefficients of urbanized catchments compared to natural systems. In rainfall-runoff analysis and modelling, the runoff coefficient indicates impact of land use on infiltration. Runoff 
coefficients for impervious pavements, roads and roofs range from 0.8 to 0.95 (Kuang and $\mathrm{Fu}$ 2013), indicating low infiltration rate and hence high runoff generation.

Urban buildings, pavements and roads also have higher thermal bulk properties and surface radiative properties than natural catchments. Together with waste heat from automobiles, industrial production, heating of households and air-conditioning, there is an increase in surface and overall ambient air temperature in urban areas, a phenomenon referred to as the urban heat island effect (Taha et al. 1991; Endreny 2008; König 2009). This urban heat island effect induces the development of convective air masses, and consequently thunderstorms, and could potentially increase vapour pressure deficit or atmospheric water demand. Vapour pressure deficit controls water vapour fluxes, especially when moisture is non-limiting (Gwenzi et al. 2012, 2013). Overall, the increase in catchment runoff coefficient, thermal regimes and diversion of roof runoff are the key mechanisms accounting for the impacts of urbanization and urban roof water harvesting systems on rainfall partitioning and the hydrological behaviour.

\subsection{Rainfall and Infiltration}

In most water-scarce regions of the world, precipitation occurs predominantly as rainfall, characterized by high spatial and temporal variability. Studies have shown that urbanization induces changes in rainfall patterns and amounts due to low air moisture, the urban heat island intensity, atmospheric instability and the presence of cloud condensation nuclei (Shepherd 2005; O'Driscoll et al. 2010). Urban surface roughness and urban canopies, such as buildings, infrastructure and trees, also affect circulation of air masses (O'Driscoll et al. 2010). The urban heat island effect alters the convection of air masses and increases the magnitude and frequency of summertime high-intensity storms (Bornstein and Lin 2000; Dixon and Mote 2003; O'Driscoll et al. 2010). For example, in Atlanta, the urban heat island effect accounted for three out of six summer convective storm events (Bornstein and Lin 2000) and induced an average of 15 storm events per year within a five-year study period (Dixon and Mote 2003). Other studies also showed that urbanization increased total rainfall by 30 to $59 \%$ compared to the pre-urbanization condition (Burian and Shepherd 2005; Mote et al. 2007). A comprehensive review of studies of urban-induced rainfall covering the period 1995-2005 is presented in Shepherd (2005). Limited information is available on urban-induced rainfall in urbanized catchments in other water-scarce regions including SSA, where high-intensity storms are common. In such regions, the effects of urbanization and urban heat island are likely to be superimposed on and enhance the inherently spatial and temporal variability of rainfall. As noted by Shepherd (2005), further studies are required to understand the complex feedbacks among urban land use, weather and climate systems at different spatial and temporal scales.

Rainfall amount and intensity, and surface conditions control infiltration (Kuang and $\mathrm{Fu}$ 2013). Therefore, urban-induced high-intensity storms falling on impervious surfaces generate lower infiltration, and consequently runoff coefficients are higher (0.80-0.95) than natural catchments (Furusho et al. 2013). The collection, storage and subsequent use of water through roof water harvesting systems result in a substantial reduction in catchment infiltration and soil moisture storage. These shifts in rainfall partitioning may in turn have adverse impacts on hydrological and ecological function of catchments. For example, the low soil moisture regimes will affect water use patterns of plant functional types, and abiotic (bare soil evaporation) and biotic (transpiration) water vapour fluxes. 


\subsection{Rainfall-Runoff Relationships}

The Hortonian infiltration excess, saturation excess and the variable source area mechanisms account for runoff generation in natural catchments (Johnson et al. 2003; McDonell 2013). Here, five key runoff characteristics are used as indicators of changes in runoff behaviour: (1) runoff generation mechanisms; (2) minimum rainfall threshold required for runoff generation; (3) timing of peak runoff response to rainfall events; (4) shifts in peak and total discharge; and (5) runoff velocity. Connected impervious surfaces, artificial slopes and channel networks in urban areas, coupled with urban-induced high-intensity storms, imply that surface runoff is dominated by infiltration excess or Hortonian overland flow (Johnson et al. 2003; Barron et al. 2011). These changes in catchment properties and runoff coefficients may have profound effects on on-site and downstream hydrographs (Fig. 1). The runoff-rainfall relationship depicted in Fig. 1 provides fundamental information on the nonlinear threshold-dependent hydrological behaviour of catchments (Hasenmueller and Criss 2013). First, the x-intercept evidently indicates that significantly higher precipitation is lost via interception and depression storage before any runoff is generated in natural than urban catchments. Second, the runoffrainfall curve fails to conform to a 1:1 relationship, demonstrating that, even after this initial demand is satisfied, the excess of effective rainfall is subject to additional losses. Furthermore, the y-intercept and slope of runoff-rainfall plot vary considerably among seasons and catchment characteristics. This runoff-rainfall relationship can be used to partition evapotranspiration into physical evaporation and biological transpiration (Hasenmueller and Criss 2013). More importantly, a graphical comparison of the y-intercepts of runoff-rainfall plots for proximal catchments both identifies and quantifies out-of-basin gains or losses of water, which can be very significant in karst areas due to groundwater flows, and in urban areas due to storm sewers (Hasenmueller and Criss 2013).

Compared to natural catchments, urbanization without rain water harvesting reduces the onsite minimum rainfall threshold required to trigger runoff, but incorporation of roof water

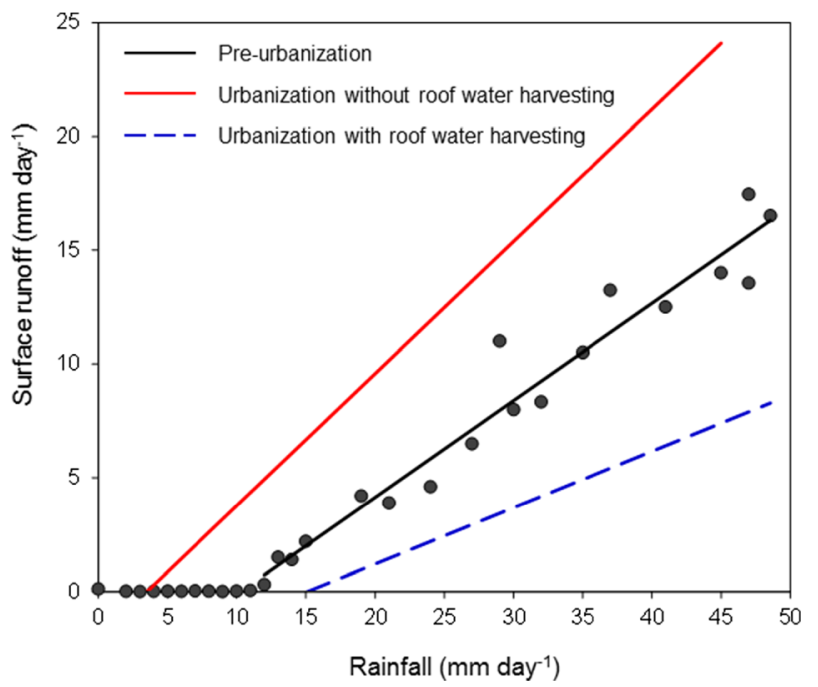

Fig. 1 Effect of urbanization with and without roof runoff harvesting on downstream rainfall-runoff relationship for a catchment in a water-limited environment. The general pre-urbanization rainfall-runoff relationship is based on data in water-limited environments indicating a minimum rainfall threshold of approximately $10-20 \mathrm{~mm} \mathrm{day}^{-1}$ (e.g., Dubreuil 1985; Ngigi et al. 2005, 2007) 
harvesting systems has the opposite effect on the downstream hydrograph (Fig. 2). Conceptual analysis and field data (Mejía and Moglen 2010; Hawley and Bledsoe 2011) indicate that urbanization and urban roof water harvesting systems cause shifts in the discharge and time components of the hydrograph relative to the baseline condition (Fig. 2). Specifically, urbanization alone reduces the time of concentration or catchment lag time, and increases peak discharge, and runoff volumes and velocity for the on-site and downstream hydrographs. By contrast, incorporation of urban roof water harvesting systems delays the arrival of the flood wave, and reduces peak discharge, runoff volumes and velocity relative to urbanization and the baseline condition (Fig. 2).

In reality, urbanized catchments in water-scarce regions consist of both impervious and natural surfaces, with the proportion covered by each surface varying considerably among catchments. As Furusho et al. (2013) remarked, the hydrology of such catchments cannot be reduced to mere runoff of impervious surfaces, but should reflect the relative contribution of the two dominant surfaces. Consequently, such catchments exhibit multi-peak hydrographs characterized by two discharge peaks for a single storm (Fig. 3). The first peak corresponds to the fast-response runoff from the impervious surfaces, while the second peak corresponds to both impervious and natural pervious surfaces (Furusho et al. 2013). The overall contribution of the impervious and natural surface to total runoff volume depends on the proportion of total surface area covered by each surface and rainfall characteristics. For example, for shortduration low intensity storms, runoff from the impervious surface may dominate the hydrograph (Fig. 3a), while for moderate duration to prolonged high-intensity storms both impervious and natural surfaces contribute to runoff (Fig. 3b and c). Overall, urban roof water harvesting systems can potentially alter rainfall-runoff relationships, which may in turn have on-site and downstream ecohydrological implications.

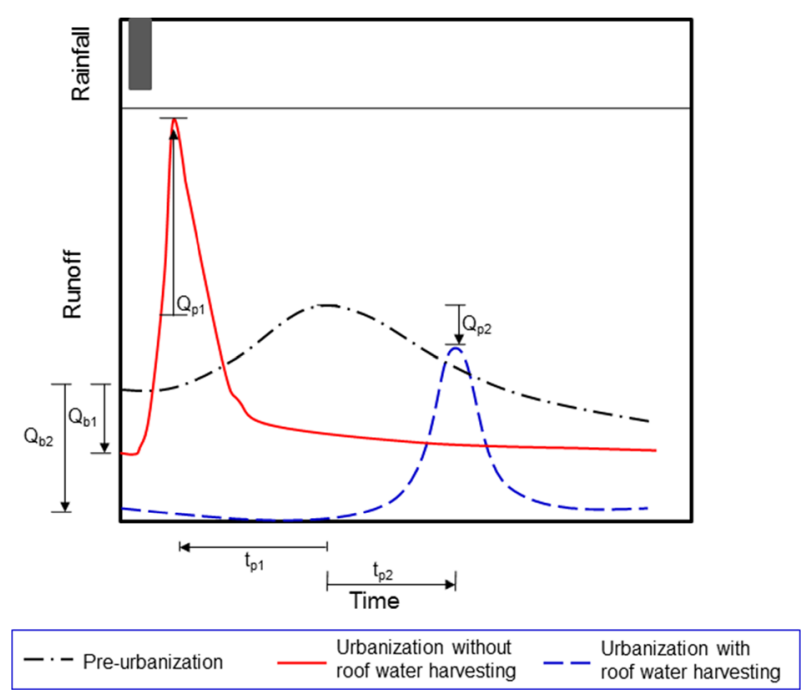

Fig. 2 Conceptual illustration of the impact of urbanization and urban roof water harvesting on hydrograph characteristics relative to pre-urbanization. Notable impacts include reduction in baseflow values $\left(\mathrm{Q}_{\mathrm{b} 1}\right.$ and $\left.\mathrm{Q}_{\mathrm{b} 2}\right)$, shifts in peak discharges $\left(\mathrm{Q}_{\mathrm{p} 1}\right.$ and $\left.\mathrm{Q}_{\mathrm{p} 2}\right)$ and their timing $\left(\mathrm{t}_{\mathrm{p} 1}\right.$ and $\left.\mathrm{t}_{\mathrm{p} 2}\right)$, and a decline in total runoff volume denoted by area under each curve. Arrows denote nature or direction of change. Note that all the hydrographs pertain to the downstream catchment runoff and excludes urban roof water harvested 


\subsection{Evapotranspiration}

Soil moisture availability and vapour pressure deficit are the key drivers of evapotranspiration (Gwenzi et al. 2012, 2013). Compared to other hydrological processes, such as runoff, the effect of urbanization on evapotranspiration is still poorly understood. This is partly due to multiple counteracting processes including increased atmospheric water demand induced by urban heat island, reduced soil moisture storage due to impervious surfaces, and increased water availability through landscape irrigation. Accordingly, the few available studies indicate that the effects of urbanization on evapotranspiration are complex and inconsistent (Stephenson 1994; Grimmond and Oke 1999; O'Driscoll et al. 2010). To elucidate the impacts of urban roof water harvesting systems on evapotranspiration, it is important to focus on the individual processes that constitute evapotranspiration: interception, bare soil evaporation and transpiration. In built environments, reduced soil moisture coupled with hydraulic barriers such as pavements, roofs and parking (Chen
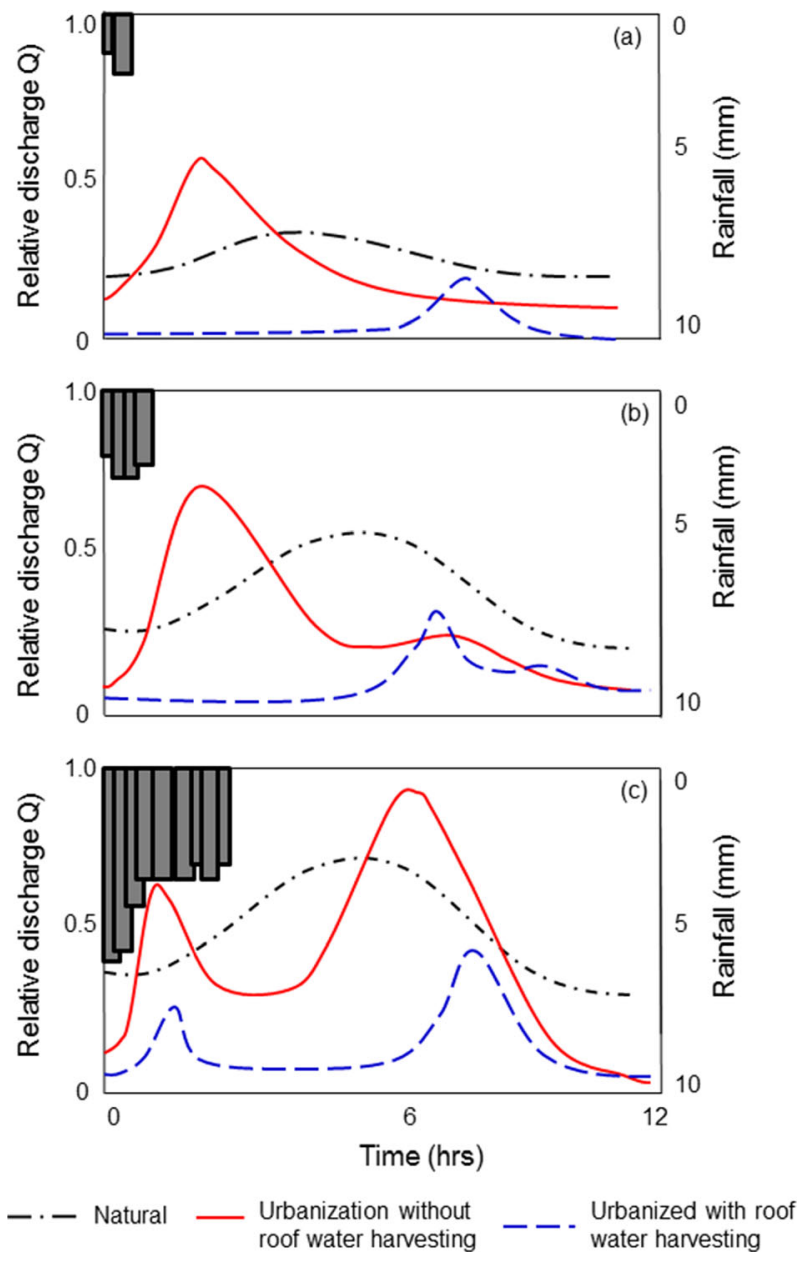

Fig. 3 Multi-peak hydrographs for urbanization with and without roof water harvesting compared to that of natural catchments for contrasting rainfall conditions: (a) short-duration low intensity storms; (b) moderate duration and intensity; and (c) persistent wet conditions with high intensity 
et al. 2011) reduce bare soil evaporation. Moreover, compared to natural vegetation canopies, artificial slopes associated with urbanization promote fast-flow of roof runoff and reduce its subsequent loss as interception. Removal of evergreen and deciduous vegetation dominant in natural ecosystems reduces root biomass and leaf area index and hence evapotranspiration (Dow and DeWalle 2000; Sun et al. 2005). The reduction in evapotranspiration is exacerbated by the heat island effect, which potentially induces a shift from perennial plant functional types to those able to cope with drought or annual species with a short distinct temporal niche (Knapp et al. 2008). Replacement of deep-rooted perennial species with annual species is well-known to reduce evapotranspiration and cause irreversible hydrological changes in water-limited environments (Cramer and Hobbs 2005; Donohue et al. 2007).

Fig. 4a and the Budyko framework (Fig. 4b) depict how urbanization and urban roof water harvesting systems may alter the long-term on-site water balance of a water-limited catchment relative to the pre-disturbance state. Assuming steady-state condition and no storage, the longterm water balance of a catchment simplifies to discharge (Q), precipitation (P) and actual evapotranspiration (ET); $Q=P-E T$. The Budyko curve plots the evaporative index $(\varepsilon)$ versus the aridity/dryness index $(\phi)$, where $\varepsilon$ is the ratio of actual evapotranspiration (ET) to the supply of water (P) (i.e., ET/P), and $\phi$ is the ratio of potential evapotranspiration (PET) or the supply of energy to the supply of water (i.e., PET/P) (Budyko 1974; Wang 2012). Vertical shifts in the Budyko curve reflect changes in rainfall partitioning between ET and Q, while horizontal shifts indicate changes in climatic conditions, particularly temperature and rainfall. Using this framework, it is evident that vegetation clearing and reduced infiltration associated with urbanization and urban roof water harvesting reduce evapotranspiration and shift the curve downwards (Fig. 4b). The downward shift in the Budyko curve, indicated in Fig. 4b, is consistent with reduced evapotranspiration and the corresponding increase in runoff or catchment yield following vegetation clearing (Sun et al. 2005; Donohue et al. 2007). Subsequent roof water harvesting reduces infiltration, soil moisture and hence evapotranspiration, further pushing the curve downwards.

Overall, while the heat island effect may promote evapotranspiration through increased vapour pressure deficit when soil is readily available, it can be concluded that in water-limited catchments, low soil moisture availability due to reduced infiltration and enhanced runoff will have an overriding effect on evapotranspiration. This conclusion is consistent with regional studies linking energy balance, catchment hydrology and land use patterns in 51 urbanized catchments in eastern and southern USA (Dow and DeWalle 2000). Dow and DeWalle (2000) reported significant decreases in watershed evapotranspiration accompanied by significant increases in sensible heating of the atmosphere with increased urban/residential development. The study further demonstrated that evapotranspiration declined by about $220 \mathrm{~mm}$ per year in a catchment with $100 \%$ urbanization. However, on relatively small catchments $\left(<1.0 \mathrm{~km}^{2}\right)$, urbanization has been observed to increase evapotranspiration (Stephenson 1994; Grimmond and Oke 1999). For example, in Vancouver, British Columbia, lawn irrigation increased evapotranspiration on a $0.21 \mathrm{~km}^{2}$ suburban area with $40 \%$ impervious cover (Grimmond and Oke 1986). Similar results were observed in a separate study conducted on a $0.75 \mathrm{~km}^{2}$ suburban catchment with $25 \%$ impervious area in Johannesburg, South Africa (Stephenson 1994). However, further research is required to confirm the applicability of these observations in other urban catchments in water-scarce regions such as SSA.

\subsection{Groundwater Recharge}

Groundwater recharge dynamics in water-limited ecosystems is a threshold-dependent process, and shows episodic behavior in response to rainfall events. The relationship between 

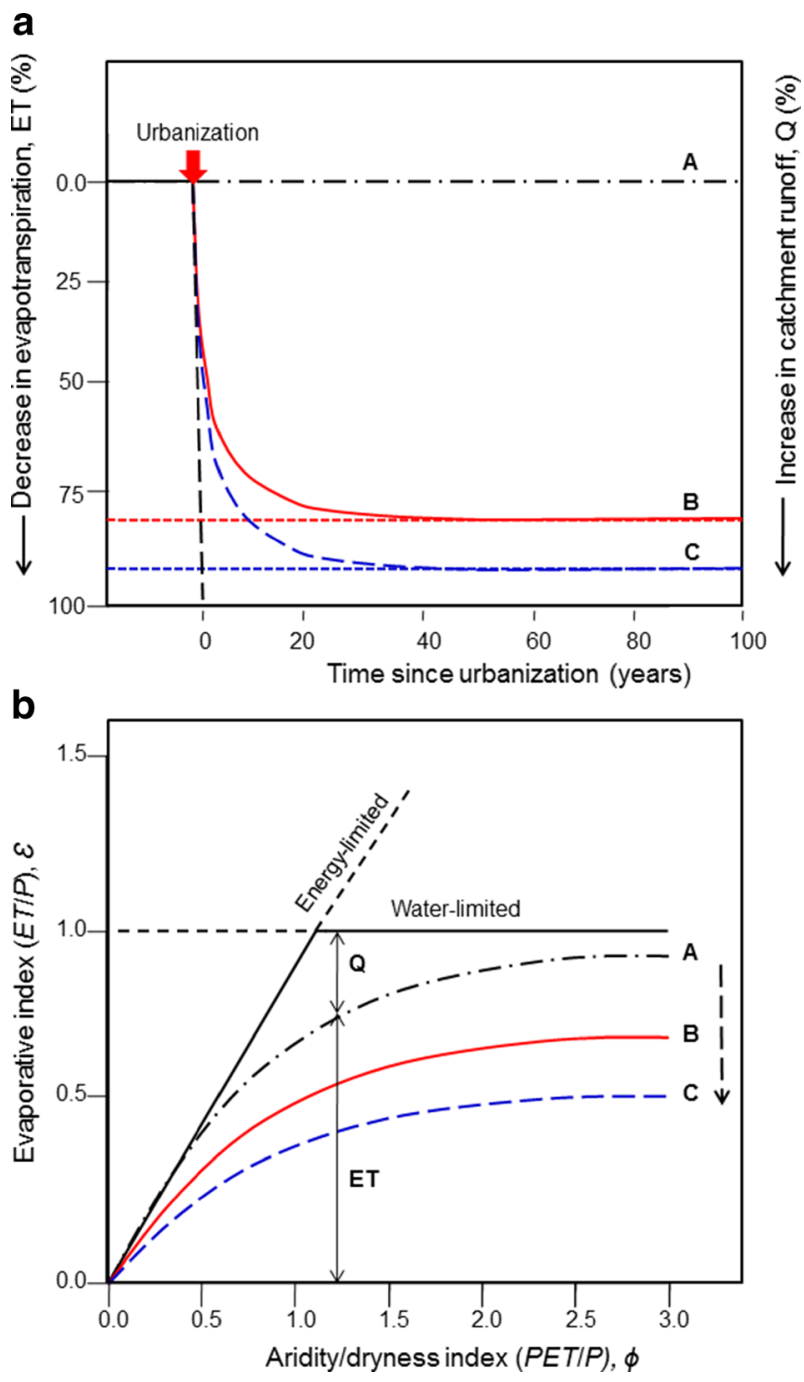

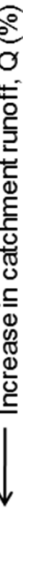

Fig. 4 (a) Depiction of reduction in catchment evapotranspiration and corresponding increase in runoff due to urbanization (B) and urban roof water harvesting (C) relative to pre-urbanization (A). (b) Conceptual location of urbanized catchment without $(\mathrm{B})$ and with $(\mathrm{C})$ roof water harvesting relative to pre-urbanization $(\mathrm{A})$ within the Budyko framework. The evaporative index $(\varepsilon)$ is the ratio of actual evapotranspiration $(E T)$ and the supply of water $(P)$, and the dryness index $(\phi)$ is the ratio of potential evapotranspiration $(P E T)$ or the supply of energy to the supply of water $(P)$ (Budyko 1974; Wang 2012)

groundwater recharge and rainfall in water-scarce regions such as SSA can be described by two non-linear functions: (1) where annual precipitation below $200 \mathrm{~mm}$ had no effect on groundwater recharge, but above $200 \mathrm{~mm}$, groundwater recharge increased almost linearly (Nonner 1997); and (2) a positive curvilinear model, characterized by an initial linear increase between annual rainfall of 200-600 mm, followed by a flatter response (Beekman et al. 1996; De Vries et al. 2000; Cavé et al. 2003).

Groundwater recharge mechanisms can be classified into four types; direct, indirect, localized and artificial (Garcia-Fresca 2004; O’Driscoll et al. 2010). Direct recharge is diffuse 
and occurs over large areas through vertical percolation of precipitation in excess of soilmoisture deficits and evapotranspiration. Indirect recharge involves percolation and lateral flow of water from surface water bodies into the groundwater system. Whereas groundwater recharge in natural catchments predominantly occurs as direct and indirect recharge, in urbanized catchments both localized and artificial recharge also occur (O'Driscoll et al. 2010). Localized recharge occurs through small features such as depressions, fractures, pipe leakages from water distribution networks, wastewater and storm-water collection systems, roof runoff and soak-aways. Indirect recharge in urban areas occurs via sinkholes, infiltration basins, grass swales along unpaved edges of pavements and roads, and detention ponds (Erickson and Stefan 2009), while artificial recharge involves deliberate injection of water and wastewater into aquifers (O'Driscoll et al. 2010).

Whereas rainwater harvesting systems practised in dryland agriculture enhance infiltration and groundwater recharge (Ngigi et al. 2007; Welderufael et al. 2011), urbanization and urban roof water harvesting systems have the opposite effect. Fig. 5 shows the expected reduction of groundwater recharge due to increase in impervious surfaces. According to Fig. 5, urbanization and roof water harvesting systems lower groundwater recharge through reduced infiltration and soil moisture storage, and diversion of runoff, respectively. Moreover, the high atmospheric water demand associated with the urban heat island effect may exacerbate groundwater depletion via evapotranspiration by isolated perennial vegetation species used for urban landscaping, although this is expected to be much lower than the pre-urbanization values. This predicted trend is consistent with a few earlier studies (Bhaduri et al. 2000; Rose and Peters 2001) showing that the long-term impact of combining urbanization and roof water harvesting systems is a receding groundwater table.

However, the widely held notion, depicted in Fig. 5, contradicts available empirical data on groundwater recharge drawn from 23 urbanized sites in arid, semi-arid and humid environments (Fig. 6) (Foster et al. 1994; Morris et al. 1994; Garcia-Fresca 2004). Studies conducted in Tehran, Iran (Shamsi and Ardeshir 1999), Buenos Aires (Bianci and Lopardo 2003) and

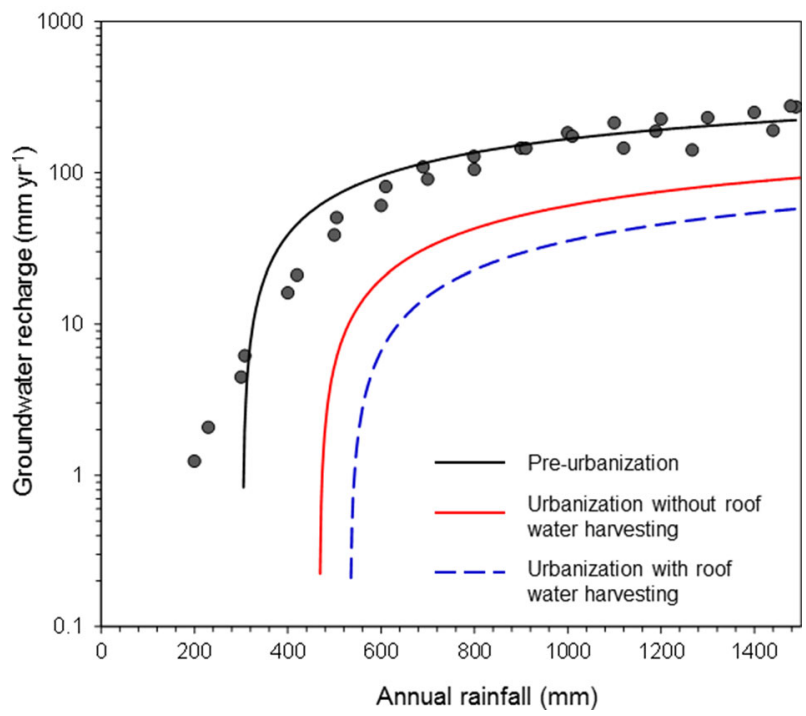

Fig. 5 Effect of urbanization with and without roof water harvesting on rainfall-recharge threshold relationship. The general trend for pre-disturbance recharge values is based on groundwater field data from Sub-Saharan Africa (Beekman et al. 1996; De Vries et al. 2000; Cavé et al. 2003) 
developing countries have also reported a rise in groundwater levels (Abu-Rizaiza 1999). Garcia-Fresca (2004) included 19 additional study sites to the original data by Foster et al. (1994) and showed that in all cases the total groundwater recharge increased under urbanization except for Birmingham, UK, where a $4 \%$ decline in recharge was observed (Fig. 6). The study further showed that urban-enhanced recharge is most significant in arid and semi-arid climates and in cities in developing countries. This unexpected trend was attributed to the introduction of new sources and pathways of recharge (Garcia-Fresca 2004). For example, the complex network of utility trenches, tunnels, and other buried structures in urban areas increase the permeability by orders of magnitude, creating hydrogeological systems analogous to natural shallow karst systems (Krothe 2002; Garcia-Fresca 2004). The urban karst system develops continuously as new structures are built and older ones are abandoned, and could provide preferential pathways for groundwater recharge and alter groundwater flow directions and velocities (Krothe 2002; Sharp et al. 2003; Garcia-Fresca 2004). Evidently, in one case study in Austin, Texas, USA, urbanization reduced annual direct recharge from $53 \mathrm{~mm}$ to $31 \mathrm{~mm}$, but urban water sources contributed $63 \mathrm{~mm}$ of annual recharge, which was nearly double that of the pre-urbanization period (Garcia-Fresca, 2004).

A number of reasons may explain the contradiction between the expected trend in Fig. 5 and empirical data (Foster et al. 1994; Garcia-Fresca 2004). First, unlike in water-scarce regions such as SSA, urban design in developed countries incorporate storm-water best management practices (BMP) or low impact development such as water retention basins, filter strips and bioretention cells (O'Driscoll et al. 2010), that could enhance groundwater recharge.

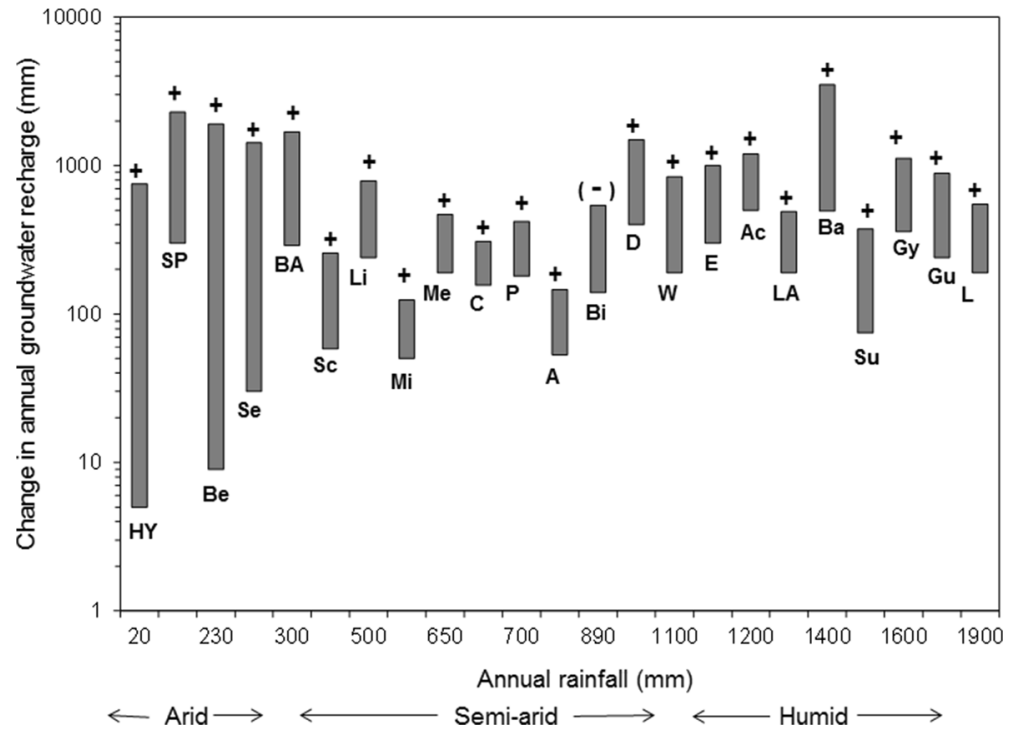

Fig. 6 Enhanced groundwater recharge caused by urbanization in twenty-three cities (except Birmingham, UK) around the world (Drawn based on data from several studies cited in Foster et al. 1994; Garcia-Fresca 2004). HY: Hat Yai, Thailand; SP: São Paulo, Brazil; Be: Bermuda, UK; Se: Seoul, Korea; BA: Buenos Aires, Argentina; SC: Santa Cruz, Bolivia; LI: Long Island (New York), USA; Mi: Milan, Italy; Me: Mérida, México; C: Caracas, Venezuela; P: Perth, Australia; A: Austin (Texas), USA; Bi: Birmingham, UK; D: Dresden, Germany; W: Wolverhampton, UK; E: Évora, Portugal; Ac: Aguascalientes, México; LA: Los Angeles (California), USA; Ba: Baku, Azerbaijan; Su: Sumgayit, Azerbaijan; Gy: Gyandja, Azerbaijan; Gu: Gulistan, Uzbekistan; L: Lima, Perú. $(+)$ and $(-)$ denote increase and decrease of recharge, respectively. The lower and uppers parts and length of each bar (except for Birmingham), represent pre-urbanization, post-urbanization and change in recharge due to urbanization, respectively 
Second, no data was provided on groundwater use, the quantity of water imported from other catchments and artificial recharge for the 23 study sites in the dataset presented. Artificial recharge of aquifers is a common practice in developed countries in water-limited environments, while cities such as Perth, Australia and Riyadh, Saudi Arabia derive a significant portion of their water from sea water desalinization plants (Foster et al. 1994). Subsequent loss of this water into aquifers through leakages and artificial recharge could account for the rise in groundwater levels. The fact that recharge exceeded annual precipitation except for Birmingham, evidently suggests indirect or artificial recharge by imported water, possibly with limited subsequent groundwater pumping.

Notably, due to general lack of hydrogeological information in water-scarce regions of the world, including SSA, none of the sites in the data set were drawn from SSA, highlighting the need for similar studies in such regions. Although subject to further research, it is likely that the impacts of urban roof water harvesting systems are likely to be site-specific and the trend observed in earlier studies (Garcia-Fresca 2005) might also hold for other water-scarce regions especially where leakages from water and wastewater distribution networks are much higher (40 to $>70 \%$ ) (Amer and Sherif 1997; Nkhuwa 1999) than those for most developed countries included in the dataset. However, in general, unlike developed countries, the lack of stormwater BMP, interbasin water transfers, desalinization plants and excessive groundwater abstraction caused lack of access to reliable and safe water supplies imply that, in most waterscarce regions urban roof water harvesting systems could result in significant drop in groundwater levels. Indeed, groundwater studies conducted in urban areas in Thailand, Mexico and Bolivia showed that although average recharge increased by about $600 \%$, groundwater levels dropped due to excessive abstraction (Morris et al. 1994). Groundwater recession may in turn have an adverse impact on surface hydrology and groundwater-dependent ecosystems (Zencich et al. 2002). For example, low groundwater recharge may reduce baseflow and dry season streamflow and adversely affect downstream aquatic ecology and wetlands. Moreover, together with changes in thermal regimes, groundwater recession may induce a shift in plant functional types from groundwater-dependent species towards drought-tolerant, annual and seasonal ones.

\subsection{Surface Water and Groundwater Contamination}

Industrial discharges, sewer and on-site sanitation systems, solid waste disposal facilities associated with urbanization act as diffuse and point sources of water pollution. Urban runoff could potentially contain sediments and a complex chemical composition of nutrients, heavy metals and organic pollutants including pharmaceuticals, petroleum hydrocarbons, hormonal or endocrine-disrupting compounds (Hoffman et al. 1982; Heberer 2002; Haggard and Bartsch 2009). Research has shown that the load and concentration of suspended solids, nutrients, heavy metals and organic pollutants from urban surface runoff are higher than that of untreated runoff from non-urbanized catchments (Jin-Liang et al. 2007; Egodawatta et al. 2009). For example, studies have documented high lead concentrations exceeding environmental guidelines in urban runoff attributed to road and highway runoff (Tsihrintzis and Hamid 1998) and roof materials (Good 1993; Davis and Burns 1999). For instance, the mean concentrations of lead in runoff from old ( $>10$ years) painted surfaces $\left(28,000 \mathrm{mg} \mathrm{L}^{-1}\right)$ was approximately 7 orders of magnitude higher than that from new (0-5 years) ones $\left(370 \mathrm{mg} \mathrm{L}^{-1}\right)$ (Davis and Burns 1999). In urban areas, chronic discharges of petroleum hydrocarbons include road and highway runoff, water and wastewater treatment plants, industrial discharges and atmospheric fallouts (Hoffman et al. 1982). 
Although there is a paucity of research data on urban runoff water quality in water-scarce regions in the developing world, the potential for runoff contamination is quite high due to several reasons. For example, due to lack of proper sanitary landfills and incinerators, solid waste from industrial and municipal sources, informal home industries, agro-processing and medical facilities are co-disposed in unsanitary open dumps, buried or burnt in open spaces. Similarly, stormwater and, raw and partially-treated industrial and wastewater from aging, poorly maintained and overloaded treatment facilities are co-discharged into a single urban drainage system before final discharge into surface water bodies. Other point sources of pollution include pit latrines and septic tanks in unsewered informal and formal settlements relying on on-site sanitation, and leakages from aging sewer pipes. Pollutants transported through catchments contribute to ecological problems such as bioaccumulation and eutrophication. For example, some natural and man-make lakes in SSA such as Lake Chivero in Zimbabwe and Lake Tanganyika in Tanzania experience hyper-eutrophication due to inflows of raw or partially treated effluent (Nyamangara et al. 2009). High levels of heavy metals, nutrients and organic pollution and fish kills have been frequently reported in a series of studies conducted on urban water reservoirs in Zimbabwe (Moyo 1997; Nhapi et al. 2002).

Urbanization introduces new sources of groundwater recharge through indirect and localized processes, such as pipe leakages and bursts from wastewater distribution network, which may act as diffuse and point sources of groundwater pollution (Morris et al. 1994). Although limited information is available on groundwater pollution from point and diffuse sources in urban catchments in developing countries, the few available studies indicate that solid waste and effluent disposal, and industrial, commercial and residential activities contribute to groundwater pollution (Hranova 2006). For example, high levels of total and faecal coliforms were detected in groundwater sampled from residential areas in Bulawayo, Zimbabwe, probably due to leakage from sewer pipes and septic tanks (Mangore and Taigbenu 2004). Similarly, long-term application of wastewater and sludge (Gwenzi and Munondo 2008), unlined solid waste dumps and cemeteries (Hranova 2006) and on-site sanitation (e.g., pit latrines) in informal peri-urban settlements (Chidavaenzi et al. 2000; Zingoni et al. 2005) significantly increased the concentrations of nutrients, coliform bacteria and heavy metals in groundwater. Other case studies documenting the impacts of pit latrines on chemical and bacteriological quality of groundwater in urban and peri-urban areas are presented in a recent synthesis of global literature (Graham and Polizzotto 2013). Groundwater contamination in urban catchment is further enhanced through surface water-groundwater interactions, which are most pronounced in fractured and shallow aquifers characterized by high porosity and permeability. Once in the groundwater system, rapid flows associated with the high permeability of the urban karst systems could facilitate contaminant transport and distribution within the aquifer. Accordingly, the environmental and public health risks of such contamination could be significant especially in water-scarce regions, where the majority of the urban and peri-urban communities depend on groundwater for domestic water supplies.

The mobilization and subsequent transport of sediments and solutes from various sources via mass flow and hydrodynamic dispersion are coupled to runoff properties such as flow tortuosity, velocity, frequency and magnitude (Gallo et al. 2013). Therefore, runoff accumulates contaminants as it flows through terrestrial systems (Morris et al. 1994; Gallo et al. 2013). Incorporation of roof water harvesting in urban areas will reduce sediment detachment and transport of suspended and dissolved contaminants through attenuation of runoff velocities and volumes, and promoting deposition of sediments and other suspended solids close to their source. However, the impacts of urbanization and urban roof water harvesting systems on the 
quality of groundwater and downstream runoff will depend largely on the ultimate disposal of the harvested runoff after use.

\section{Discussion}

Roof water harvesting systems could potentially provide safe, low-cost and readily available decentralized water for domestic and multiple livelihood uses in urban and peri-urban areas in water-scarce regions. However, the current study revealed that the hydrological impacts of combining urbanization and large-scale adoption of roof water harvesting systems could be quite significant, particularly in water-limited catchments. Specifically, the changes in rainfall patterns and amounts induced by the urban heat island effect, diversion of runoff through roof water harvesting systems and the high proportion and connectivity of impervious surfaces could have adverse impacts on on-site and downstream hydrology. These impacts include changes in rainfall partitioning, water contamination and rainfall-runoff relationships. Fig. 7 is a conceptual depiction of a catchment water balance illustrating how urbanization influences rainfall partitioning into storages and fluxes. Urbanization also directly introduces new point and diffuse sources of water pollution, but the impact of incorporating urban roof water harvesting systems on water quality is less predictable, and will largely depend on the intended use and ultimate disposal of the water. In this regard, emerging principles of ecosanitation provide one opportunity to couple urban roof water harvesting systems to sanitation. Ecosanitation calls for short-cutting or closing the existing open-ended water and material cycles in urban ecosystems at the lowest appropriate scale (Gumbo 2005). However, ecosanitation is a relatively new concept in water-scarce regions such as SSA, hence will require changes in policy, perceptions and mindset (Gumbo 2005) especially in the developing world. It is envisaged that decentralized urban roof water harvesting systems may act as precursor for ecosanitation amongst the urban and peri-urban poor in water-scarce regions.

Contrary to the widely held notion that urbanization reduces groundwater recharge through reduced infiltration caused by impervious surfaces, empirical data drawn from several semiarid and arid catchments and cities in developing countries show urban-enhanced recharge due to the introduction of additional recharge sources and flow pathways. However, critical analysis of the available studies in the context of water management practices and socioeconomic settings in water-scarce regions revealed that excessive abstraction of groundwater is likely to offset the urban-enhanced recharge, resulting in groundwater depletion. Consequently, a drop in groundwater levels may induce salt water intrusions in coastal areas, ground subsidence and adversely affect groundwater-dependent ecosystems.

The impact of combining urbanization and roof water harvesting systems on evapotranspiration was more complex and inconsistent than other hydrological processes. This was partly due to counteracting effects of reduced soil moisture and vegetation cover on one hand, and increased atmospheric water demand induced by urban heat island effect and landscape irrigation on the other hand. In general, the overall effect of urbanization and urban roof water harvesting systems on evapotranspiration will be a reflection of the balance between the counteracting processes. However, considering that soil moisture rather than atmospheric water demand predominantly controls evapotranspiration in water-limited ecosystems, we deduce that urbanization and urban roof water harvesting systems reduce evapotranspiration. These adverse on-site and downstream hydrological impacts could in turn affect terrestrial and aquatic ecosystem functions, and should be considered during the planning, designing and operation of urban roof water harvesting systems to ensure that mitigation measures are implemented. 


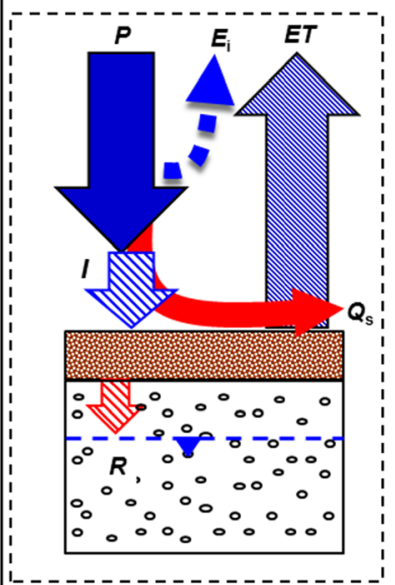

(a) Pre-urbanization

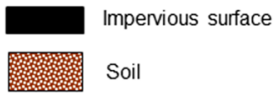

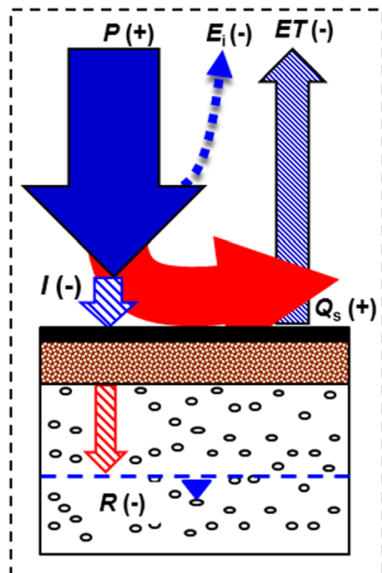

(b) Urbanization without roof water harvesting

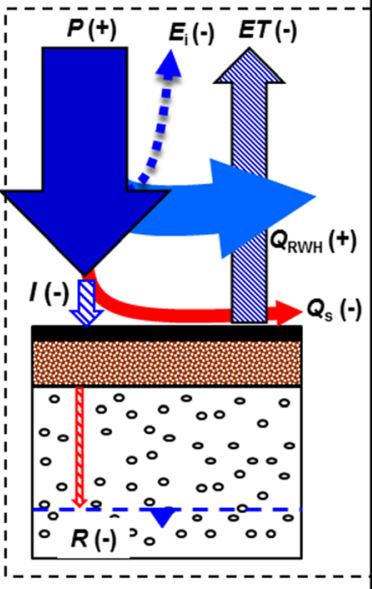

(c) Urbanization with roof water harvesting

$$
\begin{array}{ll}
\hline 00 & \text { Aquifer } \\
-\nabla^{-} \cdot & \text { Groundwater table }
\end{array}
$$

Fig. 7 Conceptual water balance depicting the impacts of urbanization with and without roof water harvesting on rainfall partitioning in a water-limited environment. $\boldsymbol{P}$ : precipitation, $\boldsymbol{E}_{\mathrm{i}}$ : interception, $\boldsymbol{I}$ : infiltration, $\boldsymbol{E T}$ : evapotranspiration (bare soil evaporation and transpiration), $\boldsymbol{Q}_{\mathbf{s}}$ : surface runoff, $\boldsymbol{Q}_{\mathbf{R W H}}$ : roof runoff and $\boldsymbol{R}$ : groundwater recharge. $(+)$ and (-) indicate increases and decreases in water balance components, respectively

The current study was based on literature review and conceptual analysis of potential hydrological impacts of urbanization and urban roof water harvesting systems. Therefore, there is urgent need for further research to confirm and extend the findings of the current study, using urbanized catchments incorporating roof water harvesting systems as case studies. In water-scarce regions, such as SSA, such future research should focus on four thematic areas: (1) roof runoff quality and its public and environmental risks; (2) groundwater recharge and levels; (3) groundwater-surface water interactions and their impacts on hydrology and contaminant transport; and (4) feedbacks between urban land use, and climate and weather systems. To this end, on-going work in Zimbabwe is focussing on quantifying roof runoff and understanding the characteristics of roof catchments and their impacts on chemical properties of runoff with respect to its suitability for domestic use (Dirwai et al. in preparation).

In most developing countries, asbestos, grass thatch, plastics, tiles and zinc-coated iron sheets are commonly used as roof material, yet, as the review revealed, there is limited empirical data on roof water quality. Given that in most developing countries roof runoff is likely to be consumed with limited or no treatment, there is need to investigate the quality of roof runoff, its determinants, and public health and environmental impacts. Studies conducted in Australia demonstrating that consumption of untreated roof water is linked to public health risks, such as disease outbreaks (e.g., Lye 2002) further stress the need for such studies.

The inconsistency between expected decline in groundwater recharge and empirical findings (Morris et al. 1994; Garcia-Fresca 2004) calls for further research. In this regard, a combination of field studies and time-lapse monitoring of groundwater recharge using recent advances in satellite technology, such as NASA's Gravity Recovery and Climate Experiment (GRACE; (http://www.nasa.gov/centers/jpl/missions/grace.html), may yield comprehensive 
insight on the impacts of urbanization on groundwater recharge and resources. GRACE satellite data has been applied successfully to estimate the spatial and temporal variability of groundwater storage and recharge in the USA (e.g., Rodell et al. 2007; Strassberg et al. 2009; Scanlon et al. 2012), but its validity and application are yet to be investigated in water-scarce regions, such as SSA.

Groundwater-surface water interactions also play a significant role in water balance and solute transport, but their contribution to hydrology and contaminant transport in urban catchments is still poorly understood. A combination of field measurements using borehole monitoring and tracer studies, and GIS-based modelling coupling a groundwater flow model, such as MODFLOW, to surface hydrology models, such as semi-distributed TOPMODEL (Beven et al. 1995) and fully-distributed TOPNET model (Ibbitt et al. 2001; Bandaragoda et al. 2004), provide ideal tools for such investigations. Such empirical studies will provide a comprehensive understanding of urban roof water harvesting systems and could potentially yield crucial information on the safe amount of roof runoff than can be harvested without adverse impacts on the biophysical environment.

Urban catchments can be considered as coupled human-dominated natural systems whose complexity and overall behaviour are governed by the two-way interactions or feedbacks among natural and anthropogenic processes. Such systems exhibit nonlinear dynamics characterized by thresholds, reciprocal feedback loops, time lags, resilience, heterogeneity and surprises (Liu et al. 2006). A typical feedback loop entails the link between urban heat island effect, rainfall and weather and climatic patterns at different spatial and temporal scales. Therefore, a systems approach, considering the feedback loops among the various components, may untangle the complexities such as emergent properties and threshold behaviour. This can lead to novel scientific discoveries essential for developing effective frameworks for ecological and socioeconomic sustainability of rainwater harvesting systems (Liu et al. 2006).

\section{Conclusions}

The review highlights the potential impacts of combining urbanization and roof water harvesting systems on on-site and downstream hydrology. It can be concluded that urbanization increases the proportion of impervious surfaces, and causes the urban heat island effect and the formation of an urban karst system. Incorporation of roof water harvesting imparts additional complexity to the unique hydrology of urban catchments. The combined effects of urbanization and roof water harvesting cause shifts in rainfall patterns and the emergence of multi-peak hydrographs. However, the effects on groundwater recharge and evapotranspiration are highly complex and reflect the balance among several counteracting processes. For instance, although the urban karst system could enhance groundwater recharge and contamination, the overall effect of urbanization and roof water harvesting will also depend on local groundwater management practices. These findings are critical for the design and operation of urban roof water harvesting systems, and provide a platform to initiate specific research on roof water harvesting systems in water-scarce regions of the world. Future research combining hydrological measurements and process modelling may provide a comprehensive understanding of these impacts.

Acknowledgments This manuscript was motivated by several discussions with personnel from the Environmental Management Agency (EMA-Zimbabwe) on the hydrological impacts of urbanization in tropical environments, to which we are very grateful. The authors declare no conflict of interest, and are solely responsible for 
research design, data collection and interpretation, and conclusions drawn thereof. We thank the editor and the four anonymous reviewers for the helpful comments that improved the quality of the manuscript.

\section{References}

Abu-Rizaiza O (1999) Threats from groundwater table rise in urban areas in developing countries. Water Int 24(1):46-52

Amer AM, Sherif MM (1997) Groundwater rise in Greater Cairo: cause and effects on antiquities. In: Chilton J (ed) Groundwater in the urban environment: problems, processes and management. Balkema, Rotterdam, pp 213-217

Bandaragoda C, Tarboton DG, Woods R (2004) Application of TOPNET in the distributed model intercomparison project. J Hydrol 298:178-201

Barron OV, Pollock D, Dawes W (2011) Evaluation of catchment contributing areas and storm runoff in flat terrain subject to urbanisation. Hydrological and Earth Systems Sc 15:547-559

Beekman HE, Gieske A, Selaolo ET (1996) GRES: Groundwater recharge studies in Botswana 1987-1996. Botswana J of Earth Sci 3:1-17

Beven KJ, Lamb R, Quinn P, Romanowicz R, Freer J (1995) TOPMODEL. In: Singh VP (ed) Computer models of watershed hydrology. Water Resources Publications, Colorado, pp 627-668

Bhaduri B, Harbor J, Engel B, Grove M (2000) Assessing watershed-scale, long-term hydrologic impacts of land-use change using a GIS-NPS model. Environ Manag 26:643-658

Bianci H, Lopardo R (2003) Diagnosis and mitigation of groundwater level rise in a highly populated urban system. Proceedings for the Congress of International Association of Hydraulic Research, v. 30, Theme B, pp 629-636.

Bornstein R, Lin Q (2000) Urban heat islands and summertime convective thunderstorms in Atlanta: Three case studies. Atmos Environ 34:507-516

Budyko MI (1974) Climate and Life. Academic, New York

Burian SJ, Shepherd JM (2005) Effect of urbanization on the diurnal rainfall pattern in Houston. Hydrol Proc 19: 1089-1103

Cavé L, Beekman HE, Weaver J (2003) Impact of climate change on groundwater recharge estimation. In: Xu Y, Beekman HE (eds). Groundwater recharge estimation in Southern Africa. UNESCO IHP Series No. 64, UNESCO, Paris, pp189-197

Chen L, Zhang Z, Li Z, Tang J, Caldwell P, Zhang W (2011) Biophysical control of whole tree transpiration under an urban environment in Northern China. J Hydrol 402:388-400

Chidavaenzi M, Bradley M, Jere M, Nhandara C (2000) Pit latrine effluent infiltration into groundwater: The Epworth case study. Schriftener Ver Wasser Boden Lufthyg 105:179-185

Coombes P (2002) Rainwater tanks revisited: new opportunities for urban water cycle management. University of Newcastle, Dissertation

Cramer VA, Hobbs RA (2005) Assessing the ecological risk from secondary salinity: A framework addressing questions of scale and threshold responses. Austral Ecol 30:537-545

Davis AP, Burns M (1999) Evaluation of lead concentration in runoff from painted structures. Water Res 33(13): 2949-2958

De Vries JJ, Selaolo ET, Beekman HE (2000) Groundwater recharge in the Kalahari, with reference to paleohydrologic conditions. J Hydrol 238:110-123

Dile YT, Karlberg L, Temesgen M, Rockström J (2013) The role of water harvesting to achieve sustainable agricultural intensification and resilience against water related shocks in sub-Saharan Africa. Agric Ecosyst Environ 181:69-79

Dirwai TL, Gwenzi W, Mhizha A (In preparation) Quantifying and chemical analysis of roof runoff in a suburban area in Harare, Zimbabwe.

Dixon PG, Mote TL (2003) Patterns and causes of Atlanta's urban heat island-initiated precipitation. J Appl Meteorol 42:1273-11284

Donohue RJ, Roderick ML, McVicar TR (2007) On the importance of including vegetation dynamics in Budyko's hydrological model. Hydrol Earth Syst Sci 11:983-995

Dow CL, DeWalle DR (2000) Trends in evaporation and Bowen ratio on urbanizing watersheds in eastern United States. Water Resour Res 36:1835-1843

Dubreuil PL (1985) Review of field observations of runoff generation in the tropics. J Hydrol 80:237-264

Egodawatta P, Evan T, Ashantha G (2009) Understanding the physical processes of pollutant build-up and washoff on roof surfaces. Sci Total Environ 407(6):1834-1841 
Endreny T (2008) Naturalizing urban watershed hydrology to mitigate urban heat-island effects. Hydrol Process 22:461-463

Erickson TO, Stefan HG (2009) Groundwater recharge in a Coldwater Stream Watershed during urbanization, Engineering, Environmental and Geophysical Fluid Dynamics Project Report No. 524. Anthony Falls laboratory, Minnesota Pollution Control Agency, Minnesota

Farreny R, Morales-Pinzón T, Guisasola A, Tayá C, Rieradevall J, Gabarrell X (2011) Roof selection for rainwater harvesting: quantity and quality assessments in Spain. Water Res 45:3245-3254

Foster SSD, Morris BL, Lawrence AR (1994) Effects of urbanization on groundwater recharge. In: Wilkinson WB (ed) Groundwater Problems in urban areas. Tomas Telford, London, pp 43-63

Furusho C, Andrieu H, Chancibault K (2013) Analysis of the hydrological behavior of an urbanizing basin. Hydro Proc. doi:10.1002/hyp.9706

Gallo EL, Brooks PD, Lohse KA, McLain JET (2013) Temporal patterns and controls on runoff magnitude and solution chemistry of urban catchments in the semiarid southwestern United States. Hydrol Process 27:995-1010

Garcia-Fresca B (2004) Urban effects on groundwater recharge in Austin. Dissertation, The University of Texas, Texas

Good JC (1993) Roof runoff as a diffuse source of metals an aquatic toxicity in storm water. Water Sci Technol 28(3-5):291-297

Graham JP, Polizzotto ML (2013) Pit latrines and their impacts on groundwater quality: A systematic review. Environ Health Perspect 121:521-530

Grimmond CSB, Oke TR (1999) Evapotranspiration rates in urban areas. In: Impacts of urban growth on surface water and groundwater quality; IAHS Publication No. 259: Wallingford, Oxfordshire, pp 235-243

Gumbo B (2005) Short-cutting the phosphorus cycle in urban ecosystems. Dissertation, UNESCO-IHE, Delft

Gwenzi W (2010) Vegetation and soil controls on water redistribution on recently constructed ecosystems in water-limited environments. University of Western Australia, Dissertation

Gwenzi W, Munondo R (2008) Long-term impacts of pasture irrigation with treated sewage effluent on shallow groundwater quality. Water Sci Technol 58(12):2443-2452

Gwenzi W, Veneklaas EJ, Bleby TM, Yunusa IAM, Hinz C (2012) Transpiration and plant water relations of evergreen woody vegetation on a recently constructed artificial ecosystem under seasonally dry conditions in Western Australia. Hydrol Process 26:3281-3292

Gwenzi W, Hinz C, Bleby TM, Veneklaas EJ (2013) Transpiration and water relations of evergreen shrub species on an artificial landform for mine waste storage versus an adjacent natural site in semi-arid Western Australia. Ecohydrology doi.org/10.1002/eco.1422

Haarhoff J, van der Merwe B (1996) Twenty-five years of wastewater reclamation in Windhoek, Namibia. Water Sci Technol 33(10):25-35

Haggard BE, Bartsch LD (2009) Net changes in antibiotic concentrations downstream from an effluent discharge. Journal of Environ Quality 38:343-352

Hasenmueller EA, Criss RE (2013) Water balance estimates of evapotranspiration rates in areas with varying land use. Chapter 1. Intechopen. doi.org/10.5772/52811. http://cdn.intechopen.com/pdfs-wm/43032.pdf. Accessed 10 May 2014

Hawley RJ, Bledsoe BP (2011) How do flow peaks and durations change in suburbanizing semi-arid watersheds? A southern California case study. J Hydrol 405:69-82

Heberer T (2002) Occurrence, fate, and removal of pharmaceutical residues in the aquatic environment: a review of recent research data. Toxicol Letters 131:5-17

Hoffman EJ, Latimer J, Mills GL, Quinn JG (1982) Petroleum hydrocarbons in urban runoff from a commercial land use area. J Water Pollut Cont Fed 5(11):1517-1525

Hranova R (2006) (ed) Diffuse pollution of water resources: Principles and case studies in the southern African region. Taylor \& Francis/Balkema, London

Ibbitt RP, Henderson RD, Copeland J, Wratt DS (2001) Simulating mountain runoff with meso-scale weather model rainfall estimates: A New Zealand experience. J Hydrol 239(1-4):19-32

Jebamalar A, Ravikumar G (2011) A comparative analysis of hydrologic responses to rainwater harvesting - a case study. Indian Journal of Science and Technology 4(1):34-39

Jin-liang H, Peng-fei D, Chi-tan A, Mui-heong L, Dong-quan Z, Man-him H, Zhi-shi W (2007) Characterization of surface runoff from a subtropics urban catchment. J Environ Sci 19:148-152

Johnson MS, Coon WF, Mehta VK, Steenhuis TS, Brooks ES, Boll J (2003) Application of two hydrologic models with different runoff mechanisms to a hillslope dominated watershed in the northeastern US: a comparison of HSPF and SMR. J Hydrol 284:57-76

Kirchner JW (2009) Catchments as simple dynamical systems: catchment characterization, rainfall-runoff modeling, and doing hydrology backward. Water Resour Res 45:1-34

Knapp S, Kühn I, Wittig R, Ozinga WA, Poschlod P, Klotz S (2008) Urbanization causes shifts in species' trait state frequencies. Preslia 80:375-388 
König KW (2009) Rainwater harvesting systems for water security in rural and urban areas. In: Barron J (ed) Rainwater harvesting: a lifeline for human well-being. A report prepared for UNEP by Stockholm Environment Institute, UNEP/SEI, Nairobi, pp 44-55

Krothe JN (2002) Effects of urbanization on hydrogeological systems: the physical effects of utility trenches. The University of Texas, Dissertation

Kuang X, Fu Y (2013) Coupled infiltration and filtration behaviours of concrete porous pavement for stormwater management. Hydrol Process 27:532-540

Liaw C-H, Tsai Y-L (2004) Optimum storage volume of rooftop rain water harvesting systems for domestic use. J Am Water Resour Assoc 40(4):901-912

Liu J, Dietz T, Carpenter SR, Alberti M, Folke C, Moran E, Pell AN, Deadman P, Kratz T, Lubchenco J, Ostrom E, Ouyang Z, Provencher W, Redman CL, Schneider SH, Taylor WW (2006) Complexity of coupled human and natural systems. Science. doi:10.1126/science.1144004

Lye DJ (2002) Health risks associated with consumption of untreated water from household roof catchment systems. J American Water Resources Associatio 38(5):1301-1306

Mangore E, Taigbenu AE (2004) Land-use impacts on the quality of groundwater in Bulawayo. Water SA 30(4): 453-464

McDonell JL (2013) Are all runoff processes the same? Hydrol Proc. doi:10.1002/hyp.10076

Mejía AI, Moglen GE (2010) Spatial distribution of imperviousness and the space-time variability of rainfall, runoff generation, and routing. Water Resour Res. doi:10.1029/2009WR008568

Morris BL, Lawrence AR, Stuart ME (1994) The impact of urbanization on groundwater, Project summary report. British Geological Survey (BGS) Technical Report WC/94/56. British Geological Survey, Nottingham

Mote TL, Lacke MC, Shepherd JM (2007) Radar signatures of the urban effect on precipitation distribution; a case study for Atlanta, Georgia. Geophys Res Letters 34:1-4

Moyo NAG (ed) (1997) Lake Chivero: A polluted lake. University of Zimbabwe Publications, Harare

Mwenge-Kahinda J, Taigbenu AE, Boroto RJ (2007) Domestic rainwater harvesting to improve water supply in rural South Africa. Phys Chem Earth 32:1050-1057

Ngigi SN, Savenije HHG, Thome JN, Rockström J, Penning de Vries FWT (2005) Agro-hydrological evaluation of on-farm rainwater storage systems for supplemental irrigation in Laikipia district, Kenya. Agric Water Manag 73(1):21-41

Ngigi SN, Savenije HH, Gichuki FN (2007) Land use changes and hydrological impacts related to up-scaling of rainwater harvesting and management in upper Ewaso Ng'iro river basin, Kenya. Land Use Policy 24(1):129-140

Nhapi I, Hoko Z, Siebel MA, Gijzen HJ (2002) Assessment of major water and nutrient flows into Chivero catchment area, Zimbabwe. Phys Chem Earth 11:783-792

Nkhuwa DCW (1999) The need for consideration of groundwater resources in urban planning in Lusaka, Zambia. In: Chilton J (ed) Groundwater in the urban environment- selected city profiles. Balkema, Rotterdam, pp 201-208

Nonner J (1997) Principles of hydrogeology. IHE Lecture Note. IHE, Delft, The Netherlands

Nyamangara J, Nyamadzawo G, Senzanje A, Bangira C (2009) The status of river water chemical pollution in Zimbabwe: A review. In: Gallo MN, Ferrari MH (eds) River pollution research progress. Nova Publishers, New York, pp 319-333

O'Driscoll M, Clinton S, Jefferson A, Manda A, McMillan S (2010) Urbanization effects on watershed hydrology and in-stream processes in the southern United States. Water 2:605-648

Rodell M, Chen J, Kato H, Famiglietti J, Nigro J, Wilson C (2007) Estimating groundwater storage changes in the Mississippi River basin (USA) using GRACE. Hydrogeol J 15:159-166

Rose S, Peters NE (2001) Effects of urbanization on streamflow in the Atlanta area (Georgia, USA): a comparative hydrological approach. Hydrol Process 15:1441-1457

Scanlon BR, Longuevergne L, Long D (2012) Ground referencing GRACE satellite estimates of groundwater storage changes in the California Central Valley. USA, Water Resource Research. doi:10.1029/ 2011WR011312

Shamsi A, Ardeshir A (1999) Pollution of Tehran groundwater. WIT Press, Southampton

Sharp JM Jr, Krothe J, Mather JD, Garcia-Fresca B, Stewart CA (2003) Effects of urbanization on groundwater systems. In: Heiken G, Fakundiny R, Sutter J (eds) Earth Science in the City, vol 56, American Geophysical Union Special Publication Series, v., pp 257-278

Shepherd JM (2005) A review of current investigations of urban-induced rainfall and recommendations for the future. Earth Interactions 9:1-27

Stephenson D (1994) Comparison of the water balance for an undeveloped and a suburban catchment. J Hydrol Science 39(4):295-307

Strassberg G, Scanlon BR, Chambers D (2009) Evaluation of groundwater storage monitoring with the GRACE satellite: Case study of the High Plains aquifer, central United States. Water Resour Res. doi:10.1029/ 2008WR006892 
Sun G, McNulty SG, Lu J, Amatya DM, Liang Y, Kolka RK (2005) Regional annual water yield from forest lands and its response to potential deforestation across the southeastern United States. J Hydrol 308:258-268

Taha H, Akbar H, Rosenfeld A (1991) Heat island and oasis effects of vegetative canopies: micro-meteorlogical field measurements. Theor Appl Climatol 44(2):123-138

Tsihrintzis VA, Hamid R (1998) Runoff quality prediction from small urban catchments using SWMM. Hydrol Process 12(2):311-329

UN (United Nations) (2011) The Millennium Development Goals Report 2011. United Nations, New York

UNEP/ISRIC (1991) World map of the status of human-induced soil degradation (GLASOD). An explanatory note (2nd ed.). UNEP, Nairobi, Kenya, and ISRIC, Wageningen

Wang D (2012) Evaluating interannual water storage changes at watersheds in Illinois based on long-term soil moisture and groundwater level data. Water Resour Res. doi:10.1029/2011WR010759

Welderufael MA, Woyessa YE, Edossa DC (2011) Hydrological impact of rainwater harvesting in the Modder river basin of central South Africa. Hydrol Earth Syst Sci Discuss 8:5051-5081

Zencich SJ, Froend RH, Turner JV, Gailitis V (2002) Influence of groundwater depth on the seasonal sources of water accessed by Banksia tree species on a shallow, sandy coastal aquifer. Oecologia 131:8-19

Zingoni E, Love D, Magadza C, Moyce W, Musiwa K (2005) Effects of a semi-formal urban settlement on groundwater quality Epworth (Zimbabwe): case study and groundwater quality zoning. Phys Chem Earth 30(11-16):680-688 